\title{
An analysis of CRM practices in the telecommunication industry in Iraq
}

\author{
Hosam Alden Riyadh ${ }^{1}$, Salsabila Aisyah Alfaiza ${ }^{2}$, Abdulsatar Abduljabbar Sultan ${ }^{3}$, \\ Munadil K. Faaeq ${ }^{4}$, Radyan Dananjoyo ${ }^{5}$ \\ ${ }^{1,5}$ Universitas Muhammadiyah Yogyakarta, Indonesia \\ ${ }^{2}$ University of Airlangga, Indonesia \\ ${ }^{3}$ Nineveh Education Directorate, Mosul, Nineveh, Iraq \\ ${ }^{4}$ Fairleigh Dickinson University, Canada
}

\begin{tabular}{l} 
Article Info \\
\hline Article history: \\
Received Oct 11, 2020 \\
Revised May 1, 2021 \\
Accepted Jun 6, 2021 \\
\hline Keywords: \\
CRM practices \\
Customer relationship \\
Firm performance \\
Telecommunication
\end{tabular}

Corresponding Author:

Hosam Alden Riyadh

Universitas Muhammadiyah Yogyakarta

Jl. Brawijaya, Geblagan, Tamantirto, Kec. Kasihan, Bantul

Daerah Istimewa Yogyakarta 55183, Indonesia

Email: Hosam.alden@umy.ac.id

\begin{abstract}
Today, concerning the capacity to react straightforwardly to client demands and offer the client a profound experience that is customized and interactive, organizations in the telecommunication industry must have the capacity to set up, support, and continue the connections toward long-term clients. This study attempts to analyze and observe the customer relationship management (CRM) practices that affect firm performance telecommunication corporations. Thus, the study employed a qualitative method, the primary data were obtained using the questionnaire, and the respondents consisted of 100 people. The results propose that customer relationships' management factors included the gathering of information, the processing of data, the management of information, the loyalty of customers, and the retention of customers with significantly related to the performance of a firm in the industry of telecommunication in Iraq.
\end{abstract}

This is an open access article under the $\underline{C C B Y-S A}$ license.

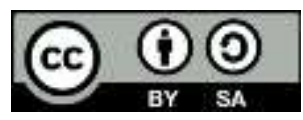

\section{INTRODUCTION}

In 2009, Iraq was generally seen as having signs of temporary civil stability, and efforts to rebuild and restore Iraq are mostly underway. It is hoped that regional tensions will not undermine this progress. From the telecom industry perspective, these stability signs permitted the mobile and fixed sectors to reconstruct and restore services. If the situation can be preserved, the highly populated Iraqi market offers an excellent chance for future telecommunication growth. There are three leading companies in the mobile sector, namely Zain Iraq, Asiacell, and Korek Telecom. These operators currently can benefit from developments related to mobile infrastructure, with signs that operators are preparing their cellular networks for $4 \mathrm{G}$ technologies. In recent years, operators have focused on restoration work focusing on repairing and replacing networks damaged or destroyed by the Civil War. These recovery efforts have partly led to a growth in mobile data usage and increased mobile data revenue. Fixed broadband networks are under deployment, and repairs are underway to repair damaged fiber optic cables. The terms improving the firm performance, marketing of relationship, and CRM are utilized nearly interchangeably [1], [2], for instance, describes the marketing of relationship as "attracting, maintaining and enhancing customer relationships." Accordingly, [3] suggests the subsequent explanation: "An organization engaged in proactively creating, 
developing and maintaining committed, interactive, and profitable exchanges with selected customers (partners) over time is engaged in relationship marketing.", lately by expanding the extent of marketing of relationship and seeing it in comprehensive management and social setting. Harker in [3], it is stated the "marketing based on relationships, networks, and interaction, recognizing that marketing is embedded in the total Management of the networks of the selling organization, the market, and society. It is directed to longterm win-win relationships with individual customers, and value is jointly created between the parties involved." The firm is supposed to focus on its key customers in CRM. They can be characterized as those whose necessities could be met by the firm's abilities. This way, at the fundamental level, firms are required to select the client's idea that it would be appropriate for serving. Based on the demography profile, the clients ought to be chosen based on the pattern of psychography, need satisfaction nature, usage frequency, and life-cycle stage. The CRM essence lies in the differentiation tenet between the clients.

Consequently, the part of "Customer Lifetime Value", in CRM, has gotten special significance. A "Customer Lifetime Value" is a practical gauge of the overall business that can be hoped from a client if he stayed loyal over his lifetime. In this regard, [4] pointed out that customers' profitability has more noteworthiness than the value of a lifetime. The writers have revealed that it is essential to know clients who benefit from those that return low profits. Another concerning issue is that advertisers yearn for the satisfaction of the client. However, it is essential to comprehend that a positive relationship between profitability and comfort could not be underestimated. Hence, the profitability of the client is a fundamental measure that is needed due to consideration for the achievement of the activity of CRM. The telecommunication sector in Iraq has managed an imposing business model. It is only operated by the government; it should be run as a private firm and be competitive. At the beginning of 2003, Iraq reported it would release the first private telecom license in the nation for mobile and fixed services. Even though in the new operator, the government would take a minority stake. General telecommunications authority (GTA) was shaped simultaneously as a new regulatory authority for the sector of telecom. The license award has been delayed several times but is expected in 2005. Nevertheless, because of its administration, the choice of CRM system application was challenging and an essential stage for its reengineering business process. The system application ought to be determined after the deal of the departments and general management. The purpose was to set up significant associations with the clients, a better administration to the clients, and advance correspondence. At present, clients are getting progressively demanding and sophisticated. They anticipate that firms should be progressively reliable and exceptionally responsive and give more services to their benefit. Firms have additionally understood the necessity to draw nearer to the clients to have the option to defeat the competition and to expand their market stock, especially in the scenario that is competitive, unstable, and fast-changing. In this modern era, most Iraqi people are using mobile, and day by day, they are getting new services from mobile operator companies. Customer satisfaction is a problem all over the world, including Iraq. There are three mobile operator companies in Iraq named Asiacell, Zain, and Korek Telecom, as is known worldwide every company has some problem satisfying the customers by providing better services, and Iraqi mobile companies are not different from that. Existing systems are not genuinely decent at associating one client to another and making sense. In Iraq's telecommunication service, some information regarding how the function is operating as well as the proposed systems, which permit them to take data about client information, customer usage, different preferences, and profitability, to utilize those data to expand the relationship of clients with the organizations have not been able to be obtained.

This study's main objective is to analyze and observe the CRM practices that affect firm performance in mobile operator companies. Thus, this study will answer the basic questions. This study is significantly different from the rest of the studies available in the literature because it will answer and clarify the relationship of CRM practices factors that influence mobile operator companies' firm performance. This study will also provide value to customers and redefine business processes for the telecommunication sector in Iraq to create more efficient and effective firms that can provide the service because of the critical factors that affect customer satisfaction. This paper's practical contributions attract new customers, retain the existing customers, and create comprehensive relationship management among them which has been the aim of every organization. This can only be achieved through a comprehensive understanding of CRM, its evolution, CRM process, and successful CRM implementation, which has motivated this study. This study will give the public and private firms solutions for implementing customer relationship management technology currently facing them. Thus, this study's structure is organized first in the introduction, second, the literature review, third methodology, fourth in the findings, and the fifth in the conclusion. 


\section{LITERATURE REVIEW}

\subsection{CRM as a business strategy}

CRM is a business strategy intended to upgrade income, profitability, and client satisfaction by sorting out the venture around client sections, encouraging client-driven practices, and actualizing clientdriven procedures [5]. It is recommended by [6] that profiling of the client, guaranteeing fulfilled members, and conveying predominant worth would help the cause of CRM. Investigations of productive CRM activities have been attempted to emphasize the significance of the cycle of the client relationship and its elements. Harding [7] called attention to the significance of upgrading the processes of business and preparing of clients before CRM execution. The management of client relationships is a primary ingredient in the value chain. The strategy is to maximize the use of CRM technologies. As a triumph factor, CRM needs significant changes and ventures in hierarchical and operational [8]. Consequently, a definitive inquiry is whether the client's orientation and the execution of client connections are significant for an organization's prosperity. Lewis and Slack [9] introduced influential and early research, which demonstrated that the client's retention has a remarkable effect on the profitability, thus explicitly demonstrating that the more drawn out the client's relationship keeps going, the more noteworthy its profitability will be the conclusions mentioned above by several researchers from different specializations underline that present client are a lot less expensive to hold than getting new clients.

\subsection{Customer loyalty}

The improvement of client loyalty includes creating and supporting a relationship with a client, which prompts the continual buying of services or items in a fixed time. Besides, the base of clients' loyalty permits firms to dedicate their efforts to different business issues. Clients can exhibit their loyalty in a few different ways. They could decide to remain with a firm, regardless of whether this continuation is characterized as a relationship or incrementing the amount of buying or both. With this investigation's end goal, loyalty is considered the conclusive outcome or the crucial component of effective CRM. Due to this, numerous researchers have recommended that loyalty is a relational occurrence. Our motivation is to connect loyalty to the development of CRM theory. Even though several researchers. [10] Recognize the loyalty of the brand, the loyalty of the store, the loyalty of sales representatives, the loyalty of product and service, this research considers the loyalty idea as the grouping of every type of it. The beginning stage for the initiative of CRM is the vision of CRM. It should be noticed that Gartner (2004) described 'Vision' as one of the eight building blocks of a triumphant venture of CRM. Vision in the CRM, as the making of an image of what the client-driven undertaking, will resemble to guarantee that competitive position can be made in the marketplace is clarified because the CRM application has essential strategies, extensive effect, and a welldeliberated vision. Nonetheless, an appropriate procedure should be implemented to figure the vision of CRM. Shahidan [11], Gordon [12] suggested the vision of CRM should be chosen before setting out on the CRM undertaking. This should be finished considering the mission, vision, standard description, and core values against which it tends to be estimated. Another methodology that assists in defining the vision of CRM depends on the essential attributes of the client and firm.

\subsection{Information gathering, processing, and management}

Information collection or information gathering is a criterion to measure that information sources are logically gathered by CRM systems. All customers' information is useful for CRM strategy-making [13]. CRM information technology collects and updates customers' information continually to understand each customer's habits. Therefore, data collection comes from all possible sources-external and internal resources, like organizations and individuals within the firm and outside. A computer-readable format stores the data, and it can easily be transformed into a database. For example, one way to collect CRM data is by using the point of sale. When a product is prepared well to sell for a customer, its bar codes could be scanned into the CRM system. Furthermore, this product relates to a particular customer and his or her account information. Sales representatives could address the customer's phone number and email address by credit cards-these two types of data record CRM process. A suitable information collection method improves the performance of CRM. McConnell and Peter [14] if the CRM systems collect data from two sources, they could record the overall business process and quickly deliver it to other organizational management. Beaven [15] market specialists can formulate an appropriate strategy for CRM when they get the data. Customers can search for any product's information published in the newspapers or the Internet in particular details to help them accomplish their requirements. The "Information Collection" criterion is to evaluate CRM systems data collected from internal and external sources. It makes information comprehensive and easy for CRM strategy-making. The management process data are related to the information, collation, client data usage, and compilation of all client contact points to produce client knowledge and proper promoting reactions. [16] The main components of material of the data regarding the process of management are the archives of data, 
which gives a memory to the corporate about clients; the systems of information technology (IT) (which incorporate the association's software, middleware, and hardware of computer); tools of analysis; and the applications of the back office and front office (which bolster the numerous activities engaged with interfacing straightforwardly with clients and overseeing administration, inner tasks, and provider connections).

In business, the critical task is to combine relationship marketing with integrated marketing effectively in a bid to establish customer loyalty [17]. As a few investigations have demonstrated, holding clients maybe provide a more feasible upper hand than procuring new ones. Significantly, there is an increasing realization among marketers that it is less costly to keep hold of clients compared to fight for the new one. The improvement of client loyalty includes creating and supporting a relationship with a client, which prompts the continual buying of services or items in a fixed time. Besides, [18] the base of clients' loyalty permits organizations to dedicate their efforts to different business issues. From this perspective, it is essential to keep the customer's hold in the Iraqi telecommunication sector compared to creating new customers. In the framework, information gathering is the first component to know about the customer as their choice, what they want from the telecommunication services, and how they get telecommunication services. In [19] to identify their satisfaction level and the service they demand, telecommunication service gathers their data such as their age, their service level such as which connection they are using, and their addresses. The archive of data gives a memory to the powerful firm about clients and incorporates a general information store equipped for critical information investigations. In more significant associations, it might contain a warehouse of information and associated information databases and stores. Two types of information warehouses are the operational information store and the conventional information warehouse. The second one stores only the data that is important to give a single identity to all clients. The management process data are related to the information, collation, client data usage, and compilation of all client contact points to produce client knowledge and proper promoting reactions. [20], [21] The main components of material of the data regarding the process of management are the archive of data, which gives a memory to the corporate about clients; the systems of IT, which incorporate the association's software, middleware, and hardware of computer; tools of analysis; and the applications of the back office and front office, which bolster the numerous activities engaged with interfacing straightforwardly with clients and overseeing administration, inner tasks, and provider connections. Thus the main hypotheses formulated as:

$\mathrm{H}_{1}$ : The gathering of information is positively related to the performance of telecommunication firms.

$\mathrm{H}_{2}$ : The process of information is positively related to the performance of telecommunication firms.

$\mathrm{H}_{3}$ : The management of information is positively related to the performance of telecommunication firms

$\mathrm{H}_{4}$ : The loyalty of the customer is positively related to the performance of telecommunication firms.

$\mathrm{H}_{5}$ : The retention of the customer is positively related to the performance of telecommunication firms.

\section{RESEARCH METHOD}

This study uses a quantitative approach. The survey is conducted by distributing questionnaires to collect the primary data. The population was three telecommunication firms in Iraq named Zain Iraq, Asiacell, and Korek Telecom, and one hundred questionnaires were distributed with an $82 \%$ ratio or 82 respondents. The stratified sampling technique is chosen for this study, and the sample of respondents was selected from customers in different areas and cities. This research was a correlation study that explored the statistical relationship between the factors that influence CRM in the telecommunication industry. To examine the data obtained in this research, it employed statistical package for the social science (SPSS) 19.0 version. For the processing of data, four statistical strategies were utilized for various goals. These are descriptive statistics, reliability tests, correlation analysis, and regression analysis. This research's data was gathered from telecommunication firms in Iraq. With different customer services, these organizations gave important information, from which we could determine our results with high generalizability. Also, the sampling was fitting in the industry of telecommunication. The first step was that the CRM implementation is extensive [22] and further developed [23], [24] in telecommunication services compared to most other industries' sectors. This research's results can give some value and edifying knowledge to associations in different sectors. Second, regardless of how telecommunication service represents a massive sector of the economy, there is a meager measure of research directed to investigate the client services and firms' experiences in offering the types of assistance through CRM in this area. This investigation can fill in the void. The sampling of non-probability convenience [25] would be selected as the design of the sampling in this examination. It would be since convenience sampling is regularly utilized during an examination venture's exploratory period and maybe is the ideal method of obtaining some fundamental data rapidly and proficiently. One hundred staff and personnel engaged with the client's management relationship would have 
been chosen for the instrument introduced in this undertaking. The questionnaire was measured by the fivepoint Likert scale from 1. Strongly disagree 2. Disagree. 3. Undecided, 4. Agree, 5. Strongly agree.

\section{FINDINGS}

\subsection{Frequency of gender}

First, the authors analyzed the respondent's gender from the 100 questionnaires. Most respondents are males, $86(86 \%)$ males, and only $14(14 \%)$ females. The result and the information of the respondent's gender are shown in Table 1.

Table 1. Gender information of respondents

\begin{tabular}{cccc}
\hline Measure & Item & Respondent $(\mathrm{N})$ & Percent $(\%)$ \\
\hline & Male & 86 & $86 \%$ \\
& Female & 14 & $14 \%$ \\
Gender & Total & 100 & $100 \%$ \\
\hline
\end{tabular}

\subsection{Correlation analysis}

Correlation coefficient test is a statistical test to test 2 variables to find out whether there is a relationship or not. The correlation value ( $r$ ) ranges from 1 to -1 , the value closer to 1 or -1 means the relationship between the two variables is getting stronger, on the other hand a value close to 0 means the relationship between the two variables is getting weaker. A positive value indicates a unidirectional relationship (X goes up then $\mathrm{Y}$ goes up) and a negative value indicates an inverse relationship (X goes up then Y goes down). Correlation categories can be divided according to the Table 2: The authors found that information gathering, and firm performance is correlated (0.35), each other at the 0.05 significant levels from the pearson correlation analysis. Information processing and firm performance correlate $(0.33)$ at 0.05 significant levels. Information management and firm performance correlated $(0.04)$ at the 0.01 significant level. Customer loyalty and firm performance correlated (0.67) at 0.01 significant levels, and customer retention and firm performance are correlated (0.47) at significant levels 0.01 as well. From this can conclude that independent variables are correlated to the dependent variables. It means that the gathering of information, the processing of information, the management of information, customer loyalty, and the retention of customers have a positive effect on the firm's performance. Based on the guidelines for providing interpretation of correlation coefficients interval coefficient relationship level, 0.00-0.199 very low, 0.200.399 low, 0.40-0.599 medium, 0.60-0.799 strong, and 0.80-1,000 very strong, when viewed from the significance value, the two variables tested are revealed have a relationship if the significance value is $<0.05$ and there is no relationship if the significance value is $>0.05$. Correlation test results can be seen in next section.

Table 2. Correlation analysis

\begin{tabular}{ccccccc}
\hline & $\begin{array}{c}\text { Gathering of } \\
\text { Information }\end{array}$ & $\begin{array}{c}\text { Process of } \\
\text { Information }\end{array}$ & $\begin{array}{c}\text { Management of } \\
\text { Information }\end{array}$ & $\begin{array}{c}\text { Loyalty of } \\
\text { Customer }\end{array}$ & $\begin{array}{c}\text { Retention of } \\
\text { Customer }\end{array}$ & $\begin{array}{c}\text { Firm } \\
\text { Performance }\end{array}$ \\
\hline $\begin{array}{c}\text { Information Gathering } \\
\text { Information }\end{array}$ & 1 & 0.126 & 0.144 & $0.583(* *)$ & $0.481(* *)$ & $0.345(*)$ \\
$\begin{array}{c}\text { processing } \\
\text { Information }\end{array}$ & 0.126 & 1 & $0.612(* *)$ & $0.354(*)$ & $0.360(*)$ & $0.333(*)$ \\
$\begin{array}{c}\text { Management } \\
\text { Customer Loyalty }\end{array}$ & 0.144 & $0.612(* *)$ & 1 & .235 & $0.289(*)$ & $0.438(* *)$ \\
Customer Retention & $0.481(* *)$ & $0.360(*)$ & $0.289(*)$ & $0.775(* *)$ & $0.775(* *)$ & $.665(* *)$ \\
Firm Performance & $0.345(*)$ & $0.333(*)$ & $0.438(* *)$ & $0.665(* *)$ & $0.466(* *)$ & $.466(* *)$ \\
\hline
\end{tabular}

$* *$ Significant at 0.01 level, $*$ Significant at 0.05 level

\subsection{Regression analysis}

In this part, the authors analyzed the regression to prove the hypothesis, which was:

$\mathrm{H}_{1}$ : The gathering of information is positively related to the performance of telecommunication firms.

$\mathrm{H}_{2}$ : The process of information is positively related to the performance of telecommunication firms.

$\mathrm{H}_{3}$ : The Management of information is positively related to the performance of telecommunication firms.

$\mathrm{H}_{4}$ : The loyalty of the customer is positively related to the performance of telecommunication firms.

$\mathrm{H}_{5}$ : The retention of the customer is positively related to the performance of telecommunication firms. 


\subsubsection{Regression analysis for information gathering and firm performance}

The authors found the relationship between information gathering and firm performance, the significant value is $\mathrm{a}=0.05$. In this result, $\mathrm{R}^{2}=0.073$, meaning that the regression equation will correctly predict $7.4 \%$ of the cases and $92.6 \%$ will not. The result revealed that information gathering, $\mathrm{F}$ change $=3.352$ and $\mathrm{p}=0.00<0.05$ has a positive relation to the performance of the firm. On this basis, it can be concluded that there is a positive relationship between information gathering and firm performance.

\section{a) Correlation and determination coefficient}

The correlation coefficient shows the magnitude of the relationship between the independent variables, namely information gathering with the firm variable, the R-value (correlation coefficient) is 0.117 , this correlation value indicates that the relationship between information gathering and the firm variable is included in the weak category because it is in the range of 0.0-0.2. The coefficient of determination is used to calculate the magnitude of the influence or contribution of information gathering on the firm variable, the coefficient of determination used is $\mathrm{R}$ square because there is one independent variable. Table 3 shows the results of $\mathrm{R}$ (coefficient of determination) of 0.073 . This means that $7.3 \%$ of firm variables will be influenced by information gathering. While the remaining $92.7 \%$ of firm variables will be influenced by other variables that are not included in this study.

Table 3. Model summary

\begin{tabular}{|c|c|c|c|c|c|c|c|c|c|c|}
\hline \multirow[b]{2}{*}{ Model } & \multirow[b]{2}{*}{$\mathrm{R}$} & \multirow[b]{2}{*}{ R Square } & \multirow[b]{2}{*}{ Adjusted R Square } & \multirow[b]{2}{*}{$\begin{array}{l}\text { Std. Error of the } \\
\text { Estimate }\end{array}$} & \multicolumn{5}{|c|}{ Change Statistics } & \multirow[b]{2}{*}{$\begin{array}{l}\text { Durbin- } \\
\text { Watson }\end{array}$} \\
\hline & & & & & $\begin{array}{c}\text { R Square } \\
\text { Change }\end{array}$ & $\begin{array}{c}\mathrm{F} \\
\text { Change }\end{array}$ & df1 & df2 & $\begin{array}{c}\text { Sig. F } \\
\text { Change }\end{array}$ & \\
\hline 1 & $.117^{\mathrm{a}}$ & .073 & .076 & .42007 & .074 & 3.352 & 1 & 98 & .000 & 1.602 \\
\hline
\end{tabular}

\section{b) Hypothesis testing}

Hypothesis testing is used to answer the hypothesis made by the researcher. Based on Table 3 , the sig value is obtained. F of 0.000 . Because the value of $\operatorname{sig} \mathrm{F}(0.000)<=0.05$, the regression analysis model is significant. This means that $\mathrm{H} 0$ is rejected and $\mathrm{H} 1$ is accepted so that it can be concluded that the firm can be significantly affected by information gathering.

\subsubsection{Regression for information processing and firm performance}

After that, in the second regression analysis between information processing and firm performance, the significant value is $\mathrm{a}=0.05$. In this result, $\mathrm{R}^{2}=0.081$, meaning that the regression equation will correctly predict $8.1 \%$ of the cases and $91.9 \%$ will not. The result revealed that information processing, $\mathrm{F}$ change = 3.048 and $\mathrm{p}=0.000<0.05$ has a positive relation to the performance of the firm. On this basis, it can be concluded that there is a positive relationship between firm performance and information processing.

\section{a) Correlation and determination coefficient}

The correlation coefficient aims to show the magnitude of the relationship between the independent variable, namely information processing with the firm variable, the $\mathrm{R}$ value (correlation coefficient) is 0.103 , this correlation value indicates that the relationship between information processing and the firm variable is included in the weak category because it is in the range of 0.2-0.4. The coefficient of determination is used to calculate the influence or contribution of information processing on the firm variable, the coefficient of determination used is $\mathrm{R}$ square because there is one independent variable. Table 4 obtained the results of $\mathrm{R}$ (coefficient of determination) of 0.081 . This means that $8.1 \%$ of firm variables will be influenced by information processing. While the remaining $91.9 \%$ of firm variables will be influenced by other variables that are not included in this study.

\section{b) Hypothesis testing}

Hypothesis testing is used to answer the hypothesis made by the researcher. Based on Table 4 obtained the value of sig. F of 0.000 . Because the value of $\operatorname{sig} F(0.000)<=0.05$, the regression analysis model is significant. This means that $\mathrm{H}_{0}$ is rejected and $\mathrm{H}_{1}$ is accepted so it can be concluded that the firm can be significantly affected by information processing. 
Table 4. Model summary

\begin{tabular}{|c|c|c|c|c|c|c|c|c|c|c|}
\hline \multirow[b]{2}{*}{ Model } & \multirow[b]{2}{*}{$\mathrm{R}$} & \multirow[b]{2}{*}{ R Square } & \multirow[b]{2}{*}{ Adjusted R Square } & \multirow[b]{2}{*}{$\begin{array}{l}\text { Std. Error of the } \\
\text { Estimate }\end{array}$} & \multicolumn{5}{|c|}{ Change Statistics } & \multirow[b]{2}{*}{ Durbin-Watson } \\
\hline & & & & & $\begin{array}{c}\text { R Square } \\
\text { Change }\end{array}$ & $\begin{array}{c}\mathrm{F} \\
\text { Change }\end{array}$ & df1 & df 2 & $\begin{array}{c}\text { Sig. F } \\
\text { Change }\end{array}$ & \\
\hline 1 & $.103^{\mathrm{a}}$ & .081 & .089 & .42072 & .081 & 3.048 & 1 & 98 & .000 & 1.531 \\
\hline
\end{tabular}

\subsubsection{Regression for information management and firm performance}

The relationship between information management and firm performance, the significant value is a $=0.05$. This result $\mathrm{R}^{2}=0.079$, meaning that the regression equation will correctly predict $7.9 \%$ of the cases and $92.1 \%$ will not. The result revealed that $\mathrm{F}$ change $=4.003$ and $\mathrm{p}=0.000<0.05$ has a positive relation to the firm's performance. On this basis, it can be concluded that there is a positive relationship between the management of information and firm performance.

\section{a) Correlation and determination coefficient}

The correlation coefficient aims to show the magnitude of the relationship between the independent variable, namely information management and the firm variable, the $\mathrm{R}$ value (correlation coefficient) is 0.075 , this correlation value indicates that the relationship between information management and the firm variable is included in the weak category because it is between 0.2-0.4. The coefficient of determination is used to calculate the influence or contribution of information management on the firm variable, the coefficient of determination used is $\mathrm{R}$ square because there is one independent variable. Table 5 obtained the results of $\mathrm{R}$ (coefficient of determination) of 0.079 . This means that $8.1 \%$ of firm variables will be influenced by information management. While the remaining $92.1 \%$ firm variables will be influenced by other variables that are not included in this study.

Table 5. Model summary

\begin{tabular}{|c|c|c|c|c|c|c|c|c|c|c|}
\hline \multirow[b]{2}{*}{ Model } & \multirow[b]{2}{*}{$\mathrm{R}$} & \multirow[b]{2}{*}{ R Square } & \multirow[b]{2}{*}{ Adjusted R Square } & \multirow[b]{2}{*}{$\begin{array}{l}\text { Std. Error of the } \\
\text { Estimate }\end{array}$} & \multicolumn{5}{|c|}{ Change Statistics } & \multirow[b]{2}{*}{$\begin{array}{l}\text { Durbin- } \\
\text { Watson }\end{array}$} \\
\hline & & & & & $\begin{array}{l}\text { R Square } \\
\text { Change }\end{array}$ & $\begin{array}{c}\mathrm{F} \\
\text { Change }\end{array}$ & df1 & df 2 & $\begin{array}{c}\text { Sig. F } \\
\text { Change }\end{array}$ & \\
\hline 1 & $.075^{\mathrm{a}}$ & .079 & .086 & .42296 & .077 & 4.003 & 1 & 98 & .000 & 1.525 \\
\hline
\end{tabular}

a. Predictors: (Constant), Information management

b. Dependent Variable: Firm performance

\section{b) Hypothesis testing}

Hypothesis testing is used to answer the hypothesis made by the researcher. Based on Table 5 obtained the value of sig. F of 0.000 . Because the value of sig $\mathrm{F}(0.000)<=0.05$, the regression analysis model is significant. This means that $\mathrm{H}_{0}$ is rejected and $\mathrm{H}_{1}$ is accepted so that it can be concluded that the firm can be significantly affected by information management.

\subsubsection{Regression for customer loyalty and firm performance}

The relationship between customer loyalty and firm performance significant value is $\mathrm{a}=0.05$. This result $\mathrm{R}^{2}=0.064$, meaning that the regression equation will correctly predict $6.4 \%$ of the cases, and $93.6 \%$ will not. The result revealed customer loyalty, $\mathrm{F}$ change $=4.481$ and $\mathrm{p}=0.000<0.05$ positively related to the performance firm. On this basis, it can be concluded that there is a positive relationship between customer loyalty and firm performance.

\section{a. Correlation and determination coefficient}

The correlation coefficient aims to show the magnitude of the relationship between the independent variable, namely customer loyalty with the firm variable, the $\mathrm{R}$ value (correlation coefficient) is 0.070 , this correlation value indicates that the relationship between customer loyalty and firm variables is included in the weak category because it is between 0.2-0.4. The coefficient of determination is used to calculate the magnitude of the influence or contribution of customer loyalty to the firm variable, the coefficient of determination used is $\mathrm{R}$ square because there is one independent variable. Table 6 obtained the results of $\mathrm{R}$ (coefficient of determination) of 0.064 . This means that $6.4 \%$ of firm variables will be influenced by customer loyalty. While the remaining $93.6 \%$ Firm variables will be influenced by other variables that are not included in this study. 


\begin{tabular}{|c|c|c|c|c|c|c|c|c|c|c|}
\hline \multirow[b]{2}{*}{ Model } & \multirow[b]{2}{*}{$\mathrm{R}$} & \multirow[b]{2}{*}{ R Square } & \multirow[b]{2}{*}{ Adjusted R Square } & \multirow[b]{2}{*}{$\begin{array}{l}\text { Std. Error of the } \\
\text { Estimate }\end{array}$} & \multicolumn{5}{|c|}{ Change Statistics } & \multirow[b]{2}{*}{$\begin{array}{l}\text { Durbin- } \\
\text { Watson }\end{array}$} \\
\hline & & & & & $\begin{array}{l}\text { R Square } \\
\text { Change }\end{array}$ & $\begin{array}{c}\mathrm{F} \\
\text { Change }\end{array}$ & df1 & $\mathrm{df} 2$ & $\begin{array}{c}\text { Sig. F } \\
\text { Change }\end{array}$ & \\
\hline 1 & $.070^{\mathrm{a}}$ & .064 & .083 & .42193 & .069 & 4.481 & 1 & 98 & .000 & 1.503 \\
\hline
\end{tabular}

a. Predictors: (Constant), Customer loyalty

b. Dependent Variable: Firm performance

\section{b. Hypothesis testing}

Hypothesis testing is used to answer the hypothesis made by the researcher. Based on Table 6 obtained the value of sig. F of 0.000 . Because the value of sig $\mathrm{F}(0.000)<=0.05$, the regression analysis model is significant. This means that $\mathrm{H}_{0}$ is rejected and $\mathrm{H}_{1}$ is accepted so that it can be concluded that the firm can be significantly affected by customer loyalty.

\subsubsection{Regression for customer retention and firm performance}

Last regression between customer retention and firm performance, the significant value is a $=0.05$. In this result, $\mathrm{R}^{2}=0.046$, meaning that the regression equation will correctly predict $4.6 \%$ of the cases, and $93.1 \%$ will not. The result revealed customer retention, $\mathrm{F}$ change $=4.726$ and $\mathrm{p}=0.000<0.05$ has a positive relation to firm performance. On this basis, it can be concluded that there is a positive relationship between customer retention and firm performance.

\section{a) Correlation and determination coefficient}

The correlation coefficient aims to show the magnitude of the relationship between the independent variable, namely customer retention with the firm variable, the $\mathrm{R}$ value (correlation coefficient) is 0.214 , this correlation value indicates that the relationship between customer retention and the firm variable is included in the weak category because it is between 0.2-0.4. The coefficient of determination is used to calculate the influence or contribution of customer retention on the firm variable, the coefficient of determination used is $\mathrm{R}$ square because there is one independent variable. Table 7 obtained the results of $\mathrm{R}$ (coefficient of determination) of 0.046 . This means that $4.6 \%$ of firm variables will be influenced by customer retention. While the remaining $95.4 \%$ firm variables will be influenced by other variables that are not included in this study.

Table 7. Model summary

\begin{tabular}{|c|c|c|c|c|c|c|c|c|c|c|}
\hline \multirow[b]{2}{*}{ Model } & \multirow[b]{2}{*}{$\mathrm{R}$} & \multirow[b]{2}{*}{ R Square } & \multirow[b]{2}{*}{ Adjusted R Square } & \multirow[b]{2}{*}{$\begin{array}{l}\text { Std. Error of the } \\
\text { Estimate }\end{array}$} & \multicolumn{5}{|c|}{ Change Statistics } & \multirow[b]{2}{*}{$\begin{array}{l}\text { Durbin- } \\
\text { Watson }\end{array}$} \\
\hline & & & & & $\begin{array}{c}\text { R Square } \\
\text { Change }\end{array}$ & $\begin{array}{c}\mathrm{F} \\
\text { Change }\end{array}$ & df1 & df 2 & $\begin{array}{c}\text { Sig. F } \\
\text { Change }\end{array}$ & \\
\hline 1 & $.070^{\mathrm{a}}$ & .064 & .083 & .42193 & .069 & 4.481 & 1 & 98 & .000 & 1.503 \\
\hline
\end{tabular}

\section{b) Hypothesis testing}

Hypothesis testing is used to answer the hypothesis made by the researcher. Based on Table 7 obtained the value of sig. F of 0.000 . Because the value of sig $\mathrm{F}(0.000)<=0.05$, the regression analysis model is significant. This means that $\mathrm{H}_{0}$ is rejected and $\mathrm{H}_{1}$ is accepted so it can be concluded that the firm can be significantly affected by customer retention.

\section{CONCLUSION}

Customer relationships management (CRM) has commonly been expected to give a competitive edge to an association and positively affect the organization's performance in telecommunication in Iraq. In this investigation, the authors have discovered that gathering information, the processing of information, the management of information, customer loyalty, and the retention of customers have a positive effect on the firm's performance. Based on the results, it could be concluded that it is critical to gather the client's data to execute CRM and perform better. These results approve the long-held belief that CRM is a fundamental achievement factor for the business's performance. Firms hoping to enhance their associations with clients 
need continually to screen their internal procedures and behavior. For marketing professionals, this research accentuates that CRM factors such as the gathering of information, the processing of information, the management of information, the customer's loyalty, and the customer's retention will determine CRM's performance quality. Then, marketing experts ought to persuade the top administration of the principal significance to keep up a genuine client emphasis to cause the firm to be crucial to clients. Exchanging costs become critical to clients within. So that the client's loyalty is a possible result with top management support on keeping up a staggering client emphasis, internal procedures, and culture ought to be client-driven to reinforce client connections. Further, marketing professionals should help spread the ideals of being genuinely client-driven using inner marketing endeavors. Finally, employees, ought to be engaged to have scope over their activities of service and capacities to deliver explicit client needs to serve in an entirely client-driven way. These findings may have some implications in developing industries like the Iraq telecommunication industry. There is a lack of evidence. Therefore, there is a need to carry out a more comprehensive investigation in the context of Iraq. Nevertheless, this study's core objective will be worthy for customer relationship management practices in the context of the Iraq telecommunication industry and its impact on firm performance. This empirical study conducted here has a few limitations. Some of the limitations can be listed as the relatively small sample size of customers. This is due to the survey's complexity, which was a direct measure of the accuracy of responses. Secondly, this could not be extended to other sectors such as manufacturing, transportation, and healthcare. Propositions for the next researchers: Customer behavior possibly significantly advantages service providers, particularly within service attributes to customization as most mobile telecommunication service providers are multinational. moreover, besides researchers could consider testing relationships investigated in different nations such as the United States of America, Japan, China, or Canada, along with several sectors to find a compromised general model utilize it in all sectors as the basic formulation for projecting changes to customer satisfaction, retention, and loyalty where product attributes vary.

\section{REFERENCES}

[1] A. Parvatiyar and J. N. Sheth, "Conceptual framework of customer relationship management," Customer relationship management: Emerging concepts, tools and applications, New Delhi, India: Tata/McGraw-Hill, 2001.

[2] S. Hajikhani, S. J. Tabibi, and L. Riahi, "The relationship between the customer relationship management and patients' loyalty to hospitals," Global journal of health science, vol. 8, no. 3, pp. 65-71, March 2016, doi: 10.5539/gjhs.v8n3p65.

[3] M. J. Harker, "Relationship marketing defined? An examination of current relationship marketing definitions," Marketing intelligence \& planning, vol. 17, no. 1, pp.13-20, 1999, doi: 10.1108/02634509910253768.

[4] N. Nasirun, S. M. Noor, A. A. Sultan, and W. M. H. W. M. Haniffiza, "Role of marketing mix and halal certificate towards purchase intention of agro based products," International Journal of Modern Trends in Business Research (IJMTBR), vol. 2, no. 7, pp. 37-46, March 2019.

[5] K. Mukerjee and K. Singh, "CRM: a strategic approach," ICFAI University Press, 2006.

[6] S. C. Jain, "CRM shifts the paradigm," Journal of strategic marketing, vol. 13, no. 4, pp. 275-291, 2005, doi: /10.1080/09652540500338329.

[7] D. Harding, "CRM's silver lining," Marketing Management, vol. 13, no. 2, pp. 27-32, 2004

[8] F. N. Jaber and L. Simkin, "Understanding customer relationship management (CRM) adoption in an Arab Middle Eastern context," Behaviour \& Information Technology, vol. 36, no. 10, pp. 1020-1036, May 2017, doi: 10.1080/0144929X.2017.1332098.

[9] M. Lewis and N. Slack, "Operations management: critical perspectives on business and management," Taylor \& Francis US, 2003.

[10] M. Noor, et al., "Customer's Quest for Quality of Products and Services Offered by Farmers' Organization," ASEAN Entrepreneurship Journal (AEJ), vol. 2, no. 2. pp. 31-41, 2016.

[11] A. N. Shahidan, "Investigating the Impact of Product Innovation and Product Quality on Brand Loyalty: Mediating Effect of Affordability: An Empirical Study on Smartphone users in Malaysia," The Middle East International Journal for Social Sciences, vol. 2, no. 2, pp. 65-72, June 2020.

[12] I. Gordon, "Best practices: Customer relationship management, " Ivey Business Journal, vol. 67, no. 2, pp. 1-5, November/December 2002.

[13] C. Low and Y. H. Chen, "Criteria for the evaluation of a cloud-based hospital information system outsourcing provider," Journal of medical systems, vol. 36, pp. 3543-3553, 2012, doi: 10.1007/s10916-012-9829-z.

[14] J. McConnell and C. Peter, "Method and system for providing information from a customer relationship management system," Google Patents, 2013.

[15] B. F. Beaven, "Processing management information," Google Patents, 2012.

[16] I. U. Bulumulla, B. Cinarkaya, Y. Sebata-Dempster, T. Sheth, A. Warshavsky, and B. Zooter,' System, method and computer program product for performing one or more actions based on a determined access permission for a plurality of users, Google Patent, 2014.

[17] E. Ruswanti and W. P. Lestari, "The Effect of Relationship Marketing Towards Customer's Loyalty Mediated by Relationship Quality," DeReMa Jurnal Manajemet, vol. 11, no. 2, pp. 34-42, 2016, doi: 10.19166/derema.v11i2.230. 
[18] V. Lepojević and S. Đukić, "Factors affecting customer loyalty in the business market-an empirical study in the Republic of Serbia," Economics and Organization, vol. 15, no. 3, pp. 245-256, 2018, doi: 10.22190/FUEO1803245L.

[19] J. Peppard, "Customer relationship management (CRM) in financial services," European Management Journal, vol. 18, no. 3, pp. 312-327, June 2000, doi: 10.1016/S0263-2373(00)00013-X.

[20] A. Payne, "Customer relationship management. the CRM-forum,"' Accessed Oct 2, 2000, 2001, pp. 25-54.

[21] U. Sekaran and R. Bougie, "Research methods for business: A skill building approach," John Wiley \& Sons, 2016.

[22] B. Burnham, "Measuring Transnational Organised Crime: An Empirical Study of Existing Data Sets on TOC with Particular Reference to Intergovernmental Organisations, "Transnational Organised Crime: Perspectives on Global Security, Routledge, 2003, pp. 65-77.

[23] M. Laketa, D. Sanadar, L. Laketa, and Z. Misic, "Customer relationship management: Concept and importance for banking sector, "UTMS Journal of Economics, vol. 6, no. 2, pp. 241-254, 2015.

[24] H. Liao, "Do it right this time: The role of employee service recovery performance in customer-perceived justice andcustomer loyalty after service failures," Journal of applied psychology, vol. 92, no. 2, pp. 475-488, 2007, doi: 10.1037/0021-9010.92.2.475

[25] M. Salah and M. Abou-Shouk, "The effect of customer relationship management practices on airline customer loyalty," Journal of Tourism, Heritage \& Services Marketing, vol. 5, no. 2, pp.11-19, 2019.

\section{BIOGRAPHIES OF AUTHORS}

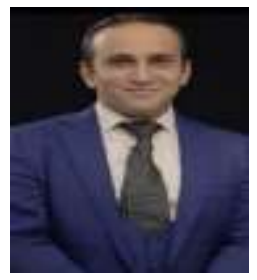

Hosam Alden Riaydh, Received a doctoral degree in Accounting from the University of Brawijaya, Indonesia. Currently working as Lecturer of accounting, at Universitas Muhammadiyah Yogyakarta. Indonesia. The main research area is interested in Corporate Social Responsibility, Accounting Information system, Management Information System, and Sustainability R eporting.

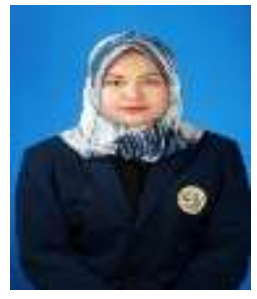

Salsabila Aisyah Alfaiza is a Master of Management Science at University of Airlangga, Indonesia. Her research interest includes management information system, corporate social responsibility, and green marketing, Supply chain, sustainability. Currently, she is working as Manager of PT. Deensajaya international company in South Java Island in Indonesia.

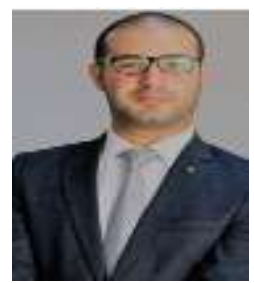

Abdulsatar Abduljabbar Sultan, a lecturer, and researcher a highly competent MIS professional with a proven track record in designing teaching, and managing databases. Ph.D. in (Technology, Operations and Logistics Management), University Utara Malaysia, Master of Science in (Management Information System), University of Mosul. His research area in Technology, Operations and Logistics Management, Management Information System E-commerce, and Technology Adoption.

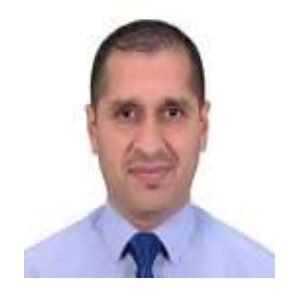

Munadil K. Faaeq received the B.Sc. degree in public administration from Baghdad University, Iraq (2002-2003). He received his Master of Business Administration (MBA) in (2008) and Ph.D. in Management Information System from the Northern University of Malaysia in (2014). He has more than 5 years of experience as a lecturer in Universities and colleges Moreover, he was appointed to be a chairman of the creativity and innovation committee in the school of business management in 2017, Director of Research, Innovation, and Commercialization Exhibition.

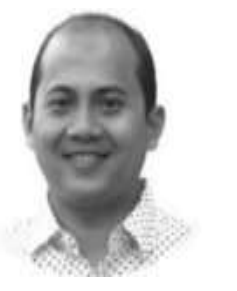

Radyan Dananjoyo is currently a Lecturer at the Faculty of Economics and Business, Universitas Muhammadiyah Yogyakarta, Indonesia. He received his Bachelor of Management from Universitas Islam Indonesia. He obtained his master's degree in international business at Groningen University, the Netherlands, and Universitas Gadjah Mada, Indonesia. He received his Ph.D. in Construction Management from Auckland University of Technology, New Zealand. 